\title{
Post-digital, Post-internet: Propositions for Art Education in the Context of Digital Cultures
}

\author{
Kristin Klein
}

Postdigital, in artistic practice, is an attitude that is more concerned with being human, than with being digital. (Post-Digital, 2019, para. 1)

\section{INTRODUCTION}

In this chapter, I address digitalization as a technological process embedded in social, political, and historical interrelations. Following a short introduction on digital cultures, I look at the genealogy of the terms Post-Digital and Post-Internet as discursive markers, originating in the field of art theory. Both terms are then extended through discussing four theses with a focus on aesthetic dimensions: (1) distributed artworks, (2) hybrid subjects, (3) fluid materiality, and (4) blind spots. Each thesis will lead to a proposition for art education research in the context of digital cultures.

\footnotetext{
K. Klein $(\bowtie)$

Univeristy of Cologne, Cologne, Germany

e-mail: kristin.klein@uni-koeln.de

(C) The Author(s) 2021

K. Tavin et al. (eds.), Post-Digital, Post-Internet Art and Education, Palgrave Studies in Educational Futures, https://doi.org/10.1007/978-3-030-73770-2_2
} 


\section{Digital Cultures}

Starting from the assumption that technologies, societies, and individuals are constituted reciprocally, it would be insufficient to conceptually base digitization primarily on technological deterministic explanations, i.e., to limit it to the history of electronic computers and digital technologies and their social influence (Baecker, 2007). On the one hand, although commonly postulated by the tech industry, digitalization does not describe an abrupt process. It is preceded by cultural-historical, social, and power-political structural conditions making cultural changes conceivable on a larger scale. One example would be, as Benjamin Jörissen (2016) states, "the organization of knowledge into proto-database-like $<$ tableaus>" (p. 26). Digitization, he concludes, is only possible to the extent that it connects to existing cultural forms and their latent transformation potentials.

On the other hand, new information and communication technologies facilitate social transformations, which in turn point beyond the respective mass medium (Baecker, 2007) book printing, for example. The mass distribution of printed products essentially contributed to the literacy of the masses and, conversely, equally necessitated acquiring cultural techniques such as reading and writing as a prerequisite for societal participation. This in turn required the establishment of new institutions such as public schools, teacher training, ministries of education, publishing houses, libraries, etc., in order to install an infrastructure for disseminating these cultural techniques (Sesink, 2008). Possibilities of critically comparing and producing printed documents grew. In the long run, concepts of individuality, authorship, and personal rights are consequently diversified (Baecker, 2007; Sesink, 2008). In sum, changes in media conditions, are accompanied by changes in subjectivation, cultural techniques and also processes of institutionalization (Jörissen \& Meyer, 2015). This connection, among others, is represented in the notion of digital cultures.

\section{Post-Digital \& Post-Internet: A Brief Introduction}

Expressions like Post-Digital and Post-Internet imply that digital technology is interwoven with social, cultural, political and also geographical environments to such an extent that it results in new cultural, symbolic, 
and material forms. Both terms surpass an understanding of digitalization in the sense of discrete units that can be transferred into binary codes or in the sense of hardware and software. The technical character of digitization takes a back seat to socio-cultural factors. The prefix post refers to relational transformation processes of material-cultural conditions (Jörissen \& Unterberg, 2019), modes of action and perception changed by digitalization (Stalder, 2017), and new (power)structures (Cramer, 2015).

Connotated in various ways, the prefix post in Post-Internet and PostDigital, is not to be understood like the prefix in post-history, which denotes the end of history, but rather in the sense of post-colonialism. Here, the prefix refers to less obvious, but no less pervasive power structures that have profound and lasting effects on languages and cultures and, above all, continue to determine geopolitics and global production chains (Cramer, 2015). Hence, the prefix post indicates that we have long since gone beyond the novelty value of digitalization. That is, we are at a point after the Internet and digital technologies were new, but at which new forms of dealing with these developments are emerging (Cramer, 2016).

The prefix is often associated with the criticism of a positional function. It is, in the eyes of artist Zach Blas (2014), an expression of uncertainty about what is, and about what can become-an empty formula. Moreover, as Blas points out, it is politically charged, alluding to the past as a compelling condition for the future. However, the prefix can also be apprehended as a productive placeholder, as a still undetermined variable that addresses the openness of digitization processes as "a zone of activity" (Bourriaud, 2002, p. 17).

\section{Post-Digital}

At the turn of the millennium, the notion Post-Digital is discussed in reference to digital technology as an expression of human desire. Restrictions of binary ways of thinking that permeate everyday life are fundamentally questioned (Pepperell \& Punt, 2000). Coming from the field of electronic music, for example, Kim Cascone (2000) uses the term Post-Digital to critically distance himself from new technological developments. Instead of associating technology with the modern promise of progress and striving for perfection, he is concerned with the possibilities 
of subversive use of technology through aesthetic means. Flaws and fractures become a theme in his work, e.g. in the form of glitches, pictorial or acoustically perceptible disturbances of digitally composed processes, and structures.

A decade later, in the context of transmediale 2013, the Berlin-based festival relating art, culture, and technology, a change in the semantic meaning of post-digitality is evident. Although still associated with a claim to a temporal and critical distance, at the same time, the admission of an undisputable involvement in a digitally imbued present becomes apparent:

Post-Digital, once understood as a critical reflection of 'digital' aesthetic immaterialism, now describes the messy and paradoxical condition of art and media after digital technology revolutions. [...] It looks for DIY agency outside totalitarian innovation ideology, and for networking off big data capitalism. At the same time, it already has become commercialized. (Andersen et al., 2014, p. 5)

Originally, the term referred to practices of subcultural, anti-institutional and anti-laboratory aesthetic arts in the context of digitalization (Cramer, 2016). Today, Post-Digital represents a hub for contemporary art and for research projects that critically reflect today's information technology, industrial and political complexes and regimes. While it is well established in the arts, the humanities and social sciences and in transdisciplinary approaches (Jandrić et al., 2018), the Post-Digital concept has so far been less prominent in art education. This is mainly due to the fact that research on digitality in art education tends to center the individual and the use of digital tools rather than systemic thinking and broader implications.

\section{POST-INTERneT}

The term Post-Internet is predominantly used in fine arts, firstly attributed to the artist Marisa Olson (Archey \& Peckham, 2014). In her view, since everything is now interwoven with digital technology, mediabased art is no longer a niche and thus no longer a differentiating category within the art field. She therefore considers the term New Media obsolete. Rather, art is now concerned with examining the digital, and the Internet specifically, on a cultural level (Débatty, 2008). Olson further intensifies her original statement a few years later: "We are now in a postinternet 
era. Everything is always-already postinternet" (Olson, 2012, p. 63). All art is therefore, to some extent, inevitably influenced by the conditions of the network society:

This understanding of the post-internet refers not to a time 'after' the internet, but rather to an internet state of mind - to think in the fashion of the network. In the context of artistic practice, the category of the post-internet describes an art object created with a consciousness of the networks within which it exists, from conception and production to dissemination and reception. (Archey \& Peckham, 2014, p. 8)

Gene McHugh (2011), in his discursive-journalistic blog on Post-Internet art, goes so far as to imply ontological shifts: "The Internet changed everything - that includes art. Post Internet artists are [...] ontological questioners" (p. 15). And further: "It's not work about the digital computer network, it's work about contemporary art's own entanglement in the digital computer network" (p. 167). Artist and philosopher Louis Doulas $(2011)$ concludes: "Post-Internet then, is not a category, but a condition: a contemporary art" (p. 2). Finally, Melissa Gronlund (2017) summarizes: "The years of post-internet art, from the mid-2000s to the mid-2010s, map out a time when the internet has gone from being a technology to a condition" (p. 214).

Post-Internet art is premised on the idea that technology is closely intertwined with culture, and with human beings. Rather than taking on a position from the distance, which is, however, not to be equated with or misunderstood as an uncritical approach (see Zahn in this publication), it identifies changes in artistic practice along the lines of networked art. The artist Artie Vierkant (2010) identifies moments, characterizing art Post-Internet as examples: "ubiquitous authorship, the development of attention as currency, the collapse of physical space in networked culture, and the infinite reproducibility and mutability of digital materials" (p. 1). They are, among others, starting points for the research focus Post-Internet Arts Education (PIAE, 2020) at the University of Cologne which Gila Kolb, Torsten Meyer, Konstanze Schütze, and I started in 2015. In different subprojects, it aims at understanding digital culture by systematically observing Post-Internet Art and in parallel zooming into specific artworks and media cultural phenomena in order to develop theoretically informed as well as practice-based models for art education in conversation with digital culture (Kolb \& Schütze, 2020; Meyer et al., 
2019). This chapter gives insight into the first findings of an interview study I conducted with ten Post-Internet artists describing how their understanding of their practice has changed in the post-digital age.

While PIAE relates to the term's broader meaning, it also takes into account a shift that occurred after 2010. When an increasing number of exhibitions and art fairs made use of and contributed to commercializing the term, skeptical voices grew louder. The critique was directed at Post-Internet Art in reduction to a specific style, often accompanied by accusations of market-driven shallowness (see Droitcour, 2014). Moreover, Post-Internet art, when referred to as a social group, mostly consisted of artists socialized in the Global North who profited from the growing importance of the term, thereby enhancing the already existing power structures. The critique gradually resulted in artists distancing themselves from Post-Internet. As the curators of the 9th Berlin Biennial aptly stated: "People clutch their tote bags a little tighter when they hear the phrases 'big data,' 'filter-bubble,' 'post-internet,' and 'anthropocene"' (KW Institute, 2016 , p. 55). At the same time, criticism concerning PostInternet in and of itself reveals a specific understanding of and demands concerning contemporary art that is also further examined in the context of PIAE.

Despite this development, the expression Post-Internet is still in use today, often synonymous or next to various other terms, among them Post-Digital and Post-Media (Cramer, 2016). It is proving to be helpful to facilitate discussions on digital culture that do not encounter digitization with the luxury of a contemplative distance, but rather assume a close involvement with the present. However, it needs to be complemented by other perspectives and voices from different backgrounds in order to do justice to today's globally networked yet hyper-diverse conditions.

\section{Post-Digital \& Post-Internet: Attempts to Understand the Present}

The essential difference between Post-Digital and Post-Internet is evident in the attitude toward digital technology: whereas the term Post-Digital initially tended to imagine a critical outside that would allow for a subversive use of technology, Post-Internet stands for informed action within existing structures of a conventional mass medium and its perfectly rendered surfaces (Cramer, 2015). In the meantime, the boundaries of 
the terms have become blurred. They can now be understood as attempts to observe and describe the present by the following assumptions:

1. Post-Digital as well as Post-Internet mark a point in time whenafter the introduction of user interfaces, web design, and social media-specialized computer skills are no longer necessary to use digital technology. It is entangled with everyday knowledge and media practices. In addition, one might add, it even has become a necessity for navigating the world today. From a global perspective, there are, nevertheless, substantial differences in how digitization manifests itself and also in terms of accessibility.

2. Both concepts acknowledge the fact that the Internet as a cultural landscape is different from what it used to be during the early days. While in the 1990s many hoped for democratization and more freedom through the Internet, connecting people among each other and allowing for more individual agency, it has now at the same time become highly commercialized and monopolized, owned for the most part by major platforms exercising their power.

3. Art referring to terms like Post-Digital and Post-Internet therefore, rather than focusing on technological innovation, examines and deals with digitality in its socio-cultural interdependencies and effects, while also being aware of related power structures.

Artworks relating to Post-Digital or Post-Internet sensibilities transcend conceptual-discursive descriptions and thus can contribute to a multidimensional understanding of digitization (Jörissen \& Unterberg, 2019). Consequently, artworks reflecting digital cultures enable other ways of imagining or dealing with digitization.

In the following, research questions that are currently associated with both terms, Post-Digital and Post-Internet, will be specified under the broader denomination digital culture. I will focus on cultural and arttheoretical aspects especially relevant to art education. Artworks and art theory become, in different ways, the subject and occasion of the analysis.

\section{Aesthetics And Technological Infrastructures}

By now, applications of computer codes, protocols, standards, and data formats majorly impact the politics of everyday life. Oftentimes, their 
influence remains invisible or incomprehensible. According to artist James Bridle (2013), aesthetics comprise the perceivable layer of socioeconomic, cultural, and political changes intertwined with technology. Visualized GPS-tracks of joggers or AI-software generating believable fake photos of people always point to technological infrastructures, as Bridle states in his ongoing study The New Aesthetic:

It is impossible $[\ldots]$ not to look at these images and immediately start to think about not what they look like, but how they came to be and what they become: the processes of capture, storage, and distribution: the actions of filters, codes, algorithms, processes, databases, and transfer protocols; the weights of datacenters, servers, satellites, cables, routers, switches, modems. Infrastructures physical and virtual; and the biases and articulations of disposition and intent encoded in all of these things. (Bridle, 2013, p. 4)

Artworks make the processes of digital networked technology, most of which cannot be perceived through human senses, tangible and allow for them to be negotiated differently, for example by combining, visualizing, and narratively linking large amounts of data and images (artworks by Forensic Architecture or Nathalie Bookchin, for example). In turn, they can become the point of departure for further aesthetic reflection and processing.

Post-Digital aesthetic theories (Berry \& Michael, 2015; ContrerasKoterbay \& Mirocha, 2016) consult art, design, and everyday cultural phenomena for information about, for instance, processes of relationality and subjectivity in the context of digitality. Likewise, the term aesthetic as I use it in this text is not restricted to the narrower meaning of sensory perception, but also refers to societal and cultural conditions. The next four sections explore digital culture in aesthetic aspects, each introduced by a short thesis (in italics), which is then elaborated and complemented by art as well as educational theory. In their abbreviated, thesis-like form, they are to be understood as an initial offer for orientation and further discussion. Importantly, I want to invite readers to keep in mind that ideas of distribution, hybridity, and fluidity are only one expression of digital cultures. The continuities and traditions of art education are by no means to be neglected or automatically obsolete. On the contrary, I imagine the present as searching for dialogue with the past and future. 


\section{Distributed Artworks}

In digital cultures, new modes of art production, distribution, and reception become increasingly important, leading to a new understanding of artworks as well as authorship.

Compared to predecessors in art history, digital artifacts, or photos of artworks can be changed, coupled, divided, and brought into different contexts at an unprecedented level and speed. In the mode of postproduction (Bourriaud, 2002), artistic self-understanding shifts. Now that all digital reproductions are potentially changeable, artists increasingly make use of the culturally given as raw material by remixing, copying, pasting, and translating existing forms and cultural codes into new ones (Meyer, 2015). Ryan Trecartin's montaged films, for instance, through exaggeration, quotation, and recombination of, among others, memetic gestures, visual effects, sounds, and language at a high frequency, highlight and make visible qualities of digital culture such as modifiability and interconnectedness. Here, symbolic forms of digital culture are superimposed, thereby emphasizing the symbolic codes of their representation (Zahn, 2017).

At the same time, current cultural practices change familiar modes of reflection and valorization systems. This can be observed, for example, in the status of the artwork. On the premise of postproduction, art is not necessarily to be understood as an "original work" (Meyer, 2015) or auratic object. Trecartin's films, for instance, while being exhibited in the professional art world, are in many cases freely available online. They are widely distributed and subjected to the Internet's logic of attention and reproducibility.

Online, aesthetic strategies differ from more traditional practices in at least two aspects. Firstly, they combine human-machine interaction and algorithmized modes of perceiving, distributing, and producing artworks (Leeker, 2018). Secondly, they are characterized by dynamics of databased (knowledge) production from which new cultural configurations and practices emerge (Manovich, 1999). Developing an understanding of both algorithmic processes and data architectures in their social implications can be enhanced by discussing artworks structurally. Here, the networked image, the associations and relations between images and image populations (Joselit, 2013; Sabisch \& Zahn, 2018) as well as distributed 
aesthetics (Gye et al., 2005; Schütze, 2020) come into play. In this way, and this is my first proposition, art education takes into account image circulation, platforms, hashtags, links, and likes as crucial elements of art and digital cultures.

\section{Hybrid Subjects}

Digital cultures require new approaches to the (aesthetic) subject, which is fundamentally a hybrid, networked subject.

In digital cultures which are increasingly dependent on and influenced by algorithmic logics and database-compatible world production, the question arises of how subjectivity can currently be comprehended (Jörissen, 2017). Artists Dorota Gawęda and Eglè Kulbokaité, for example, locate fictional characters like Agatha Valkyre Ice (Ai) equally in Google docs, in game spaces as well as in galleries. $A i$ is collectively embodied, in nomadic situations, by human actors as well as through space, algorithms, and devices that are likewise conceived of as actors, altogether forming a hybrid network (Rafferty, 2017).

In view of such concepts, art education faces new challenges concerning the allocation of agency and the addressability of a subject capable of acting. Currently, network-theoretical and posthuman theories define subjectivation as the co-constitution of material and discursive relations of nature, culture, and technology by human and nonhuman actors (Barad, 2007). Thus, the pervasive centrality of human actors in the humanistic sciences of the Global North is contrasted with alternative theoretical models. Similarly, reflections on networked subjects can be found in Actor Network Theory (Latour, 2005), New Materialism (Bennett, 2010; Dolphijn \& van der Tuin, 2012), Object Oriented Ontology (Bogost, 2012), and, in some cases distancing themselves from the term itself, Posthumanism (Braidotti \& Hlavajova, 2018; Haraway, 2016). All of them put emphasis on ecological, political, and social issues by overcoming notions of nature-culture/humantechnology dichotomies which tended to overlook the hegemonic forces of technological-cultural apparatuses (Kanderske \& Thielmann, 2019).

The notion of hybrid subjects establishes new prerequisites for art education, e.g., in conceptualizing participation (Götz, 2019; Leeker, 2018) or inclusion (Hahn, 2019) that is not limited to human actors. 
Instead, subjectivity here is entangled with digital devices as well as physical settings. Against the background of globally networked societies, new understandings of the subject are also reflected in collaborative forms of teaching and learning (Rousell \& Fell, 2018) and more generally referring to questions of mediatization, e.g., in the idea of the learning network and communities (Jörissen \& Meyer, 2015). In all of the aforementioned positions, the idea of an individual subject does not disappear, yet becomes less prominent. Thinking about educational infrastructures and enabling situations to collectively negotiate the terms and conditions of learning from each other, come to the forefront. This leads me to my second proposition: Now that every information is accessible at the fingertips, consciously inventing new ways of dealing with digital devices, but also of sharing time and space, especially, considering their agential potential, seems ever more important.

\section{Fluid Materiality}

Digitality permeates materiality and co-constitutes it.

Since the 1970s, digitalization had often been discussed one-sidedly regarding topoi of virtuality and simulation (Kanderske \& Thielmann, 2019). Portable devices, the Internet of Things, and sensory environments not least have ensured that this insufficient concentration on, or criticism of, alleged digital immateriality has been conceptually expanded to physical, sensory, and affective qualities. In digital cultures, materiality is the basis (digital terminals, interfaces), object (digitalization of analog media), and product (digital production of material phenomena, e.g. by 3D printing) of digitality (Jörissen \& Underberg, 2019). Digital artifacts can take on very different forms and states. In Lincoln 3D Scans, for example, the artist Oliver Laric captures cultural artifacts through 3D scans. The 3D models' data are made available online, they can be downloaded, edited (e.g., printed as a 3D sculpture, animated as a GIF) and then uploaded again to an online gallery (Lincoln 3D, 2013).

Processing further and translating the object into different forms and material states is an essential principle here. The artist, Morehshin Allahyari uses a similar procedure in her Material Speculations (Allahyari, 2015/2016) to reconstruct destroyed cultural assets in Syrian and Iranian war zones to save them from oblivion. Laric and Allahyari's works 
conserve the objects precisely by circulating different versions, making them publicly available and malleable. Accordingly, an idea can only be considered alive if copied, used, and expanded by others, especially beyond the boundaries of the art world. In the sense of Post-Internet Art, physical object and digitized object are different versions of an idea: "The actual work is embedded in hybrid spaces; it is simultaneously code, digital object and material object" (Jörissen, 2016, p. 3, translated from German by the author).

Specifically considering digital transformation and reformation possibilities, digital materiality is an important area of research in art education. Theoretical approaches such as the abovementioned Actor Network Theory, New Materialism and Object-Oriented Ontology acknowledge digital things or objects (Hahn, 2019) or bodies of images (see Schütze in this publication) in terms of their affordances. They are also reflected in curriculum research (Hood \& Kraehe, 2017; Rousell \& Fell, 2018). Moreover, ecological, climate policy, and power theoretical questions, e.g., technical infrastructures and resource consumption, come to the fore again through concepts such as Post-Digitality (Broeckmann, 2017).

Art education dealing with digital cultures, and this marks my third proposition respectively observation, puts emphasis on material relations and manifestations in its various states of aggregation. At the same time, transferring one state to another always comes with a certain data loss. Identifying qualities that cannot be translated and stay out of our reach, however, only continues a competence already ingrained into art education research (Sabisch \& Zahn, 2018).

\section{DigitAL IMAGINARIES}

Discourses of digitization show blind spots that need critical revision.

Both the discussions around the term Post-Internet as well as Post-Digital are limited predominantly to the Global North, excluding a wide spectrum of experiences and expertise (Gronlund, 2017). In the academic field of art education, there are only few explicit connections between digital and postcolonial, respectively, queer theory (cf. Smith in this publication). Although numerous exhibitions, projects, and initiatives could be named (e.g. DEAR HUMANS, 2020), researching automated discrimination, biased data, or software design and their effects has not 
been institutionalized widely (Braidotti, 2019). Artist Tabita Rezaire, for example, points out that technology has always been permeated by ideologies and never neutral. In her works, she contours the intertwining of technology and (post-) colonialism, counteracting unequal power structures reproduced both on- and offline (Rezaire, 2019).

In addition, there are numerous other questions that cannot be addressed here but are important to develop further: Which fantasies and desires are inscribed in technologies and which ones are they in turn producing? What kinds of effects and collective ideas are offered? How can technology be used in different ways? In this fourth proposition, that which is speculative, that which is perhaps otherwise, that which is not yet realized and that which is missing are part of art educational research: the digital imaginaries. This may be one of art education's strongest points concerning digital cultures: to observe, to advance commentary, to enact aesthetic strategies to make abstract connections tangible. Art education can not only enhance understanding digital technology but also imagine how it might become otherwise, e.g., by making visible and reframe the norms of algorithmic governance like Tabita Rezaire or by finding new ways of using technology in collaborative settings like Dorota Gawęda and Eglè Kulbokaitè.

\section{SUMMARY}

The chapter firstly explored digitization primarily defined not as a technological constant, but rather from the perspective of societal interdependencies. This is also taken into account by concepts such as Post-Digital as well as Post-Internet, even though each taking on different approaches and attitudes toward technology. In art education, the prefix post at this point still seems necessary to mark debates aiming not only at the competent use of technical devices, but also observing socio-cultural dynamics and conditional structures.

Subsequently, aesthetic dimensions connected to Post-Digital and Post-Internet or, more generally speaking, digital cultures, were presented in exemplary theses. Instead of reducing aesthetics, in a narrow sense, to what can be perceived by human senses, the conditions of aesthetic production were addressed in four areas of inquiry: 1. distributed artworks, 2. hybrid subjects, 3. fluid materiality, and 4. digital imaginaries. These examples - certainly there are many more-contribute to understanding digital cultures in their multiple entanglements. It hereby 
is important to note, as mentioned before, that characteristics of distribution, fluidity, and ungraspable hybridity represent only one manifestation of digital cultures. At the same time, there are always counterpoints equally important, especially in the field of education that is increasingly influenced by neoliberal ideas of flexibility and versatility.

Art education, as I have outlined throughout this text, is already contributing to Post-Internet and, respectively, Post-Digital research. It reflects, for instance, aesthetic codes, distributed image populations, or translations of digitally co-created materiality into different states. At the same time, projects like Post-Internet Arts Education, develop new models and methodologies on the basis of broader research implications to build tools for practical application. The Workbook Arts Education (myow, 2020) is one example.

Art education plays an important role in advancing possibilities of active participation and using digital technology in alternative, inventive ways. Simultaneously, art education can also explore what eludes digitalization and what cannot be transferred into binary codes.

\section{REFERENCES}

Allahyari, M. (2015/2016). Material speculation: ISIS (2015-2016). http:// www.morehshin.com/material-speculation-isis/.

Andersen, C. U., Cox, G., \& Papadopoulos, G. (2014). Postdigital research. editorial. APRJA, 3(1), 5 .

Archey, K., \& Peckham, R. (Eds.). (2014). Art post-internet: INFORMATION/DATA. Copy \#2. https://staticl.squarespace.com/static/5la6747de 4b06440al62a5eb/t/5ab019a9aa4a99dde60bdd5a/1521490402725/art_ post_internet_2+\%281\%29.pdf.

Barad, K. (2007). Meeting the universe halfway: Quantum physics and the entanglement of matter and meaning. Durham University Press.

Baecker, D. (2007). Studien zur nächsten Gesellschaft. Suhrkamp.

Bennett, J. (2010). Vibrant matter. Duke University Press.

Berry, D. M., \& Michael, D. (Eds.). (2015). Post-digital aesthetics: Art, computation and design. Palgrave Macmillan.

Blas, Z. (2014). Contra-Internet Aesthetics. In O. Kholeif (Ed.), You Are Here. Art After the Internet (pp. 87-97). Cornerhouse \& SPACE.

Bogost, I. (2012). Alien phenomenology, or what it's like to be a thing. University of Minneapolis Press.

Bourriaud, N. (2002). Postproduction. Lukas \& Sternberg.

Braidotti, R. (2019). Posthuman knowledge. Polity Press. 
Braidotti, R., \& Hlavajova, M. (Eds.). (2018). Posthuman glossary. Bloomsbury.

Bridle, J. (2013). The new aesthetic and its politics. http://booktwo.org/not ebook/new-aesthetic-politics/.

Broeckmann, A. (2017). Zur Post-Digitalen Ästhetik der „Post-Internet Art”. http://www.mikro.in-berlin.de/wiki/tiki-download_file.php?fileId=59.

Cascone, K. (2000). The Aesthetics of Failure: 'Post-Digital' Tendencies in Contemporary Computer Music. Computer Music Journal, 24(4), 12-18.

Contreras-Koterbay, S., \& Mirocha, Ł. (Eds.). (2016). The new aesthetic and art: Constellations of the post-digital. Institute of Network Cultures.

Cramer, F. (2015). What is 'post-digital'? APRJA. http://www.aprja.net/whatis-Post-Digital/.

Cramer, F. (2016). Nach dem Koitus oder nach dem Tod? Zur Begriffsverwirrung von „Post-Digital“, „Post-Internet“ und „Post-Media“. Kunstforum International, 242, 54-67.

DEAR HUMANS. (2020). DEAR HUMANS, ... ART SCIENCE LAB I. https://tu-dresden.de/kustodie/ausstellungen/altana/Mensch_4.0? set_lan guage $=$ en.

Débatty, R. (2008). Interview with Marisa Olson. We Make Money Not Art. https://we-make-money-not-art.com/how_does_one_become_marisa/.

Dolphijn, R., \& van der Tuin, I. (2012). New materialism: Interviews \& cartographies. Michigan Publishing, University of Michigan Library. http:// quod.lib.umich.edu/o/ohp/11515701.0001.001.

Doulas, L. (2011). Within post internet, part one. http://s3.amazonaws.com/ arena-attachments/191659/f9920b982e5457c97374810db32c6924.pdf?139 0438645 .

Droitcour, B. (2014, November). The perils of post-internet art. Art in America. https://www.artnews.com/art-in-america/features/the-perilsof-post-internet-art-63040/.

Götz, M. (2019). Post-Digital - post-partizipativ? Diskurse und Praktiken der Teilhabe in der aktuellen Medienkunst am Beispiel von Nadja Buttendorfs \#HotPhones - high-tech self-care. In K. Klein \& W. Noll (Eds.), Postdigital Landscapes. Kunst und Medienbildung in der digital vernetzen Welt (pp. 2740). Online Zeitschrift Kunst Medien Bildung | zkmb http://zkmb.de/wpcontent/uploads/2019/10/Postdigital-Landscapes.pdf.

Gronlund, M. (2017). Contemporary art and digital culture. Routledge.

Gye, L., Munster, A., \& Richardson, I. (2005). Distributed aesthetics. The Fibreculture Journal. http://seven.fibreculturejournal.org/.

Hahn, A. (2019). Everythings matter. In K. Klein \& W. Noll (Eds.), Postdigital Landscapes. Kunst und Medienbildung in der digital vernetzen Welt (pp. 90-100). http://zkmb.de/wp-content/uploads/2019/10/PostdigitalLandscapes.pdf. 
Haraway, D. J. (2016). Staying with the trouble. Making Kin in the Chthulucene. Duke University Press.

Hood, E. J., \& Kraehe, A. M. (2017). Creative matter: New materialism in art education research, teaching, and learning. Art Education, 70(2), 32-38.

Jandrić, P., Knox, J., Besley, T., Ryberg, T., Suoranta, J., \& Hayes, S. (2018). Post-digital science and education. Educational Philosophy and Theory. https://doi.org/10.1080/00131857.2018.1454000.

Jörissen, B. (2016). < Digitale Bildung > und die Genealogie digitaler Kultur: Historiographische Skizzen. MedienPädagogik. Zeitschrift für Theorie und Praxis der Medienbildung, 25, 54-67. http://doi.org/10.21240/mpaed/25/ 2016.10.26.X.

Jörissen, B. (2017). Subjektivation und „ästhetische Freiheit“ in der PostDigitalen Kultur. Wissensplattform Kulturelle Bildung Online. http://www. kubi-Retrieved from.de/artikel/subjektivation-aesthetische-freiheit-PostDigitalen-kultur.

Jörissen, B., \& Meyer, T. (Eds.). (2015). Subjekt Medium Bildung. Medienbildung und Gesellschaft (Vol. 28). Springer.

Jörissen, B., \& Unterberg, L. (2019). Digitalität und Kulturelle Bildung. Ein Angebot zur Orientierung. In B. Jörissen, S. Kröner, \& L. Unterberg (Eds.), Forschung zur Digitalisierung in der Kulturellen Bildung (pp. 11-24). kopaed.

Joselit, D. (2013). After art. Princeton University Press.

Kanderske, M., \& Thielmann, T. (2019). Virtuelle Geografien. In D. Kasprowicz \& S. Rieger (Eds.). Handbuch Virtualität (pp. 1-23). Springer VS.

Kolb, G., \& Schütze, K. (2020). Post-Internet Art Education als kunstpädagogisches Handlungsfeld. In T. Meyer, J. Eschment, \& A. Rodonò (Eds.), Arts Education in Transition. Ästhetische Bildung im Kontext kultureller Globalisierung und Digitalisierung (pp. 261-271). kopaed.

KW Institute for Contemporary Art. (2016, September 18). Catalogue of the 9th Berlin Biennale for Contemporary Art 4.6.

Latour, B. (2005). Reassembling the social-An Introduction to ANT. Journal of Chemical Information and Modeling. https://doi.org/10.1017/cbo978110 7415324.004.

Leeker, M. (2018). (Ästhetische) Vermittlung 2.0. Von Kunst-/Vermittlung und Kritik in digitalen Kulturen. In A. Sabisch, T. Meyer, H. Lüber, \& E. Sturm (Eds.), Kunstpädagogische Positionen. Volume 40. Universitätsdruckerei.

Lincoln 3D. (2013). The collection, Lincoln, \& Oliver Laric. https://www.lincol n3dscans.co.uk/.

Manovich, L. (1999). Database as symbolic form. Convergence: The International Journal of Research into New Media Technologies 5(2), 80-99. https://doi. org/10.1177/135485659900500206. 
McHugh, G. (2011). Post internet. Notes on the internet and art. 12.29.09 > 09.05.10. Link Editions.

Meyer, T. (2015). What's Next, Arts Education? Fünf Thesen zur nächsten Kulturellen Bildung. Wissensplattform Kulturelle Bildung Online. http:// www.kubi-online.de/artikel/whats-next-arts-education-fuenf-thesen-zur-naechsten-kulturellen-bildung.

Meyer, T., Zahn, M., Herlitz, L., \& Klein, K. (2019). Post-internet arts education research (PIAER). Kunstpädagogik und ästhetische Bildung nach der postdigitalen Entgrenzung der Künste. In: B. Jörissen, S. Kröner, \& L. Unterberg. (Eds.), Forschung zur Digitalisierung in der Kulturellen Bildung (pp. 171-182). kopaed.

myow. (2020). Workbook arts education. http://myow.org/.

Olson, M. (2012, November). Postinternet. Foam Magazine, Issue 29, 59-63.

Pepperell, R., \& Punt, M. (2000). The Postdigital Membrane: Imagination, Technology and Desire. Intellect Books.

PIAE. (2020). Post-internet arts education. Project Website. http://piaer.net/.

Post-Digital. (2019). https://en.wikipedia.org/wiki/Postdigital.

Rafferty, P. (2017). Becoming Ai: The artists behind Agatha Valkyrie Ice discuss the project as the post-gender avatar's crib closes at Oslo10. https://www. aqnb.com/2017/04/19/becoming-ai-the-artists-behind-agatha-valkyrie-icediscuss-the-project-as-the-post-gender-avatars-crib-comes-to-a-close/.

Rezaire, T. (2019). Artist website. http://www.tabitarezaire.com.

Rousell, D., \& Fell, F. V. (2018). Becoming a work of art: Collaboration, materiality and posthumanism in visual arts education. International Journal of Education Through Art, 14(1), 91-110. https://doi.org/10.1386/eta.14.1. 91_1.

Sabisch, A., \& Zahn, M. (Eds.). (2018). Visuelle Assoziationen. Bildkonstellationen und Denkbewegungen in Kunst, Philosophie und Wissenschaft. Textem.

Schütze, K. (2020). Bildlichkeit nach dem Internet. Aktualisierungen für eine Kunstvermittlung am Bild. kopaed.

Sesink, W. (2008). Bildungstheorie und Medienpädagogik. Versuch eines Brückenschlags. In J. Fromme, \& W. Sesink (Eds.), Pädagogische Medientheorie (pp. 13-35). VS.

Stalder, F. (2017). Kultur der Digitalität (2nd edition). Suhrkamp.

Vierkant, A. (2010). The image object post-internet. Retrieved from http://jstchi llin.org/artie/pdf/The_Image_Object_Post-Internet_us.pdf.

Zahn, M. (2017). „Wir stammen von Animationen ab.“ Wirklichkeitserfahrung mit Ryan Trecartins Videos. Online Zeitschrift Kunst Medien Bildung | zkmb. http://zkmb.de/wir-stammen-von-animationen-ab-wirklichkeitserfah rung-mit-ryan-trecartins-videos/. 
Open Access This chapter is licensed under the terms of the Creative Commons Attribution 4.0 International License (http://creativecommons.org/licenses/ by $/ 4.0 /$ ), which permits use, sharing, adaptation, distribution and reproduction in any medium or format, as long as you give appropriate credit to the original author(s) and the source, provide a link to the Creative Commons license and indicate if changes were made.

The images or other third party material in this chapter are included in the chapter's Creative Commons license, unless indicated otherwise in a credit line to the material. If material is not included in the chapter's Creative Commons license and your intended use is not permitted by statutory regulation or exceeds the permitted use, you will need to obtain permission directly from the copyright holder.

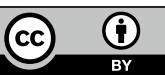

